\title{
Revealing the Orientation of the Post-Reformation Islamic Student Movement in Indonesia
}

\author{
Ahmad Izudin \\ Prodi Pengembangan Masyarakat Islam, Universitas Islam Negeri Sunan Kalijaga
}

Recieved: Io Juli 2020

Revised: 20 Agustus 2020

Published: 27 April 202I

\begin{abstract}
Abstrak:
This article explains the traces of the post-reformation Islamic student movement. The movement is still considered as the power of civil society to conduct democratization, but its tendency does not lead to social transformation. Sidney Tarrow (1996) used a theory of collective behavior reference in social movements to discuss this issue. This article is based on a qualitative research method. The data were collected by using Focus Group Discussion, interview, documentation, and literature review. This study finds out that an orientation shifting of the Islamic student movement, which is interesting to reveal. The shifting indicates the tendency to change orientation accordingly to the national political change and fluctuations. In this situation, the Islamic student movement has experienced several social dynamics. A new movement model arises when they use social media as an alternate form to convey their social criticism like through the street demonstration to critize governance practices.
\end{abstract}

Keywords:

social movement; students' organization; Islam; social transformation

\section{Introduction}

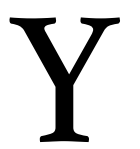

outh has an essential role in seizing the nation's independence from colonialism. History recorded the struggle for freedom, which is often linked to the national youth movement's account (Anderson, I988; Anwar, I980; Raillon, Tamara, \& Simanjuntak, 1985; Surjomihardjo, I980; Widjojo, 1999). The youth movement can be social control over the government. Social control appears when the civil community experiences social unrest because of the lack of state in handling social welfare and justice. Moreover, the nation's critical condition is dominated by collusion, corruption, and nepotism (KKN). This political situation requires the youth generation to take to the streets by speaking people's aspirations.

The 1998 student movement's empirical study is a moral and political force Usman (1999) to encourage transformative local democratization (Akbar, 20I6). However, all of these are still trapped in acts of political pragmatism. The pragmatism

\section{Korespodensi:}

Program Studi Pengembangan Masyarakat Islam, Fakultas Dakwah dan Komunikasi, UIN Sunan Kalijaga, Jl. Kampus Timur Jl. Marsda Adisucipto, Papringan, Caturtunggal, Kec. Depok, Kabupaten Sleman, Daerah Istimewa Yogyakarta 55281.

Email: ahmad.izudin@uin-suka.ac.id. 
brings in solidarity actions of social movement ineffectively when collective interests are not conveyed to political stakeholders. The labor movement in South Korea (Pamungkas, 20II), the farmer movement in Maitan Village (Harsasto, 2020), the Parangkusumo community movement in the Geo Martim Park conflict (Izudin \& Suyanto, 2019) and the conflict of Jatigede Reservoir development and oligarchic politics in Karawang (Ananta, 20I7; Rachmawan, 20I6), only a few cases of social movements are mentioned here. These movements occur as part of the severe social justice problem's struggle due to political pragmatism and political oligarchy.

This research was conducted to understand the post-reform Islamic student movement trend and analyzed qualitatively Nawawi (1992: 97) the tendency of shifting. Sources of research data consisted of Focus Group Discussions (FGD), interviews, documentation research, and literature reviews. The interview transcripts were the result of discussions, and FGDs with activists of the Muhammadiyah Student Association or Ikatan Mahasiswa Muhammadiyah (IMM), the Indonesian Islamic Student Movement or Pergerakan Mahasiswa Islam Indonesia (PMII), the Indonesian Islamic Student Action or Kesatuan Aksi Mahasiswa Islam Indonesia (KAMII), and the Islamic Student Association or Himpunan Mahasiswa Islam (HMI) - all data collection processes were carried out in Yogyakarta. Interviewees are activists in every student organization activity. Other supporting data is also used to enrich the data consisting of journals, theses, dissertations, and research reports related to the student movement.

This study focuses on student social movements that are experiencing polarization and becoming a new entity. It happens because of differences in ideology, strategy, and organizational ways. Because of this change, the post-reform student movement has decreased, especially the real action in the social realm. The student movement is no longer based on the community's mids' social-life problem but tends to be involved in political pragmatism. Thus, the student movement cannot be the agent of social change in a transformative path. The tendency is only an accidental movement.

For this reason, this research traces the orientation of the post-reform Islamic student movement. What is the direction of the post-reform Islamic student movement? How is the movement dynamics going on? Does the Islamic student movement have a form of struggle for the future?

\section{Collective Behavior: Social Movement Discourse}

Youth aspirations - we agree on this discourse, students are equal to or become part of youth - always closely related to social solidarity action. Social solidarity action is also a morality movement on social phenomena. Besides, the social solidarity movement has become a space for student self-actualization, which is always connected with social change agents and social control agents. It means that the 
student movement is similar to a social movement. The patterns and actions lead to a collective model (collective behavior). According to Tarrow (1996), the nature of social movements has significance and focuses on four aspects, namely collective challenges, common goals, solidarity, and sustainable collective action. These four focuses are essential to studying social movements (Tarrow, 1996: 3-6).

The collective model in a social movement is the action of mass groups sensitive to state hegemony. Social movements are on the struggle agenda for social change. Three critical elements accompany this struggle: political opportunity, the mobilization process, and issue framing (Tarrow, 1996: 8I-I35). Theoretical this research is following three essential elements. In this way, the political dimension becomes the social capital for the mass groups to realize freedom from the authority hegemonic oppression. This pressure is an expression to show the achievement of social movements following the initial goals. Therefore, political opportunities for political actors can provide chances for external parties from other social movements with each individual's goals.

Social movement studies have developed into political power and cultural force. Both developments serve as a critique of Castells, Touraine, Habermas, and Melucci's concerning theory of the New Social Movement. The emergence of the new paradigm is an anti-thesis for the last of the social movement model. These discourses have also become rich-colored because of the novel ideas for collective action in social movement studies. In general, collective action is a logical consequence of the cultivation of narration in the world. All social movement models are segmented in terms of the strength of collective action (Buechler, 1995).

In the other cases, social movement literacy in several Muslim countries is also included in development typology. This typology indicates technological advances that cause society to be more responsive with open political attitudes. The open society is also identified as a complex socio-political activity problem in Muslim countries (Bayat, 2005). It creates a new paradigm that is more inclusive and creates communication patterns that tend to be challenging to understand.

The variety of communication patterns in collective action is a direct effect on the world-changing globally. However, collective action stimulates a more stable mass action feature-often referred to as social solidarity. Its model emerged after the second world war, which prioritized state policy changes by demanding justice and prosperity. As a discourse, solidarity not only encourages a feature in debating 'new' or 'old' social movement, but it leads to changes in society's structure due to the existence of a new social class (Latoszek, 2006).

Hence, social movement discourse has refreshed social science. This refreshment contributes to a frame as this research references. The author built the structure questioning the use of theory in grounded research applications as a multiinterpretation of the phenomenological approach. The author uses this discourse as an analytical approach and a literature review. As literature, the author places the theory for a reference in terms of developing research. Meanwhile, as a research 
analysis, the author uses it as a thinking framework to find new phenomena; after that, it will be analyzed using the latest social movement study's perspective. The theory used to concern collective action refers to the Tarrow theory. As illustrated in the following research framework.

Figure I. Conceptual Framework

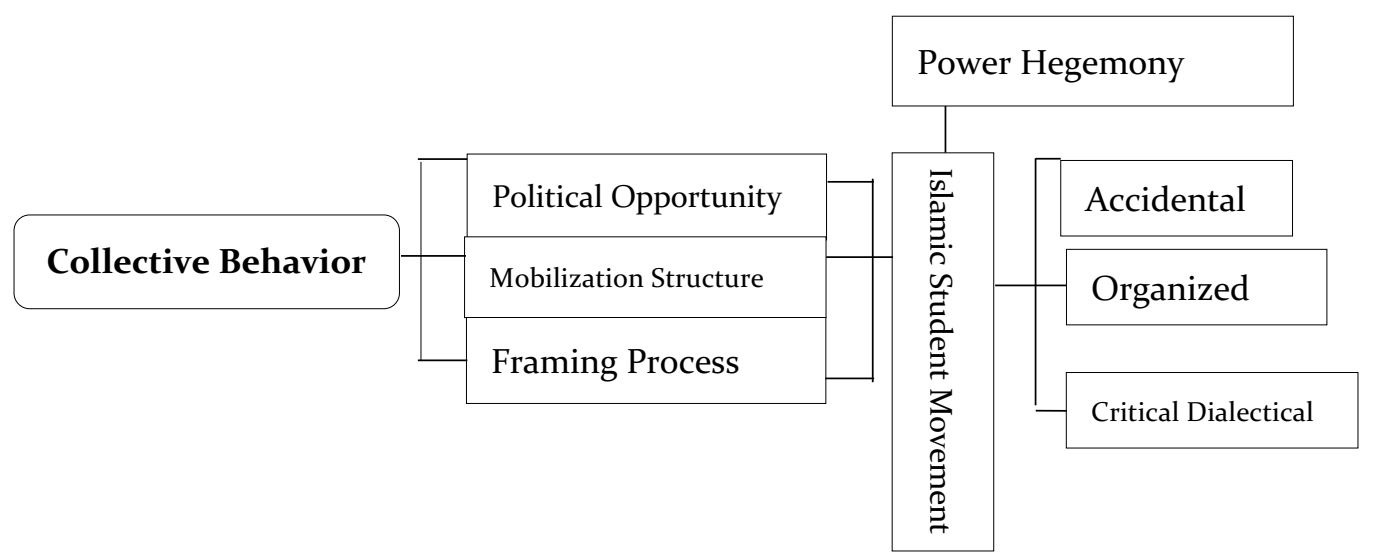

Source: Processed primary data, 2018.

The three frameworks above-political opportunity, mobilization structure, and framing process-refer to (Tarrow, 1996). First, political opportunity emphasizes the effect of structuring the political system on opportunities for collective action. Political opportunity mechanisms attempt to explain social movements caused by political structure changes (Situmorang, 2007: 3). This model departs from Tarrow's analysis, which seeks to examine forms of political tension; social movements, revolution, nationalism, and democratization (Tarrow, 1996). Political opportunity is a social movement mechanism that emerges in open political institutions. This context becomes a political balance of conflicts of interest. Its conflict is a new force in collective action to change the political structure controlled by the elite.

Second, the mobilization structure in social movements is an activity to stimulate the formation of new patterns in real student action. The structure of mobilization is a collective space, both formal and informal. Through this model, the students are expected to mobilize and blend in collective action. The concept of mobilization concentrates on informal networks, social movement organizations, and community groups. Also, the mobilization structure appears as a social mechanism related to collective actions. Collective action becomes a way to gain sympathy from several mass action segments, strengthen networks, and seek sympathizers for social advocacy work. Thus, collective action becomes a way to encourage all mass action groups (Situmorang, 2007: 7; Tarrow, 1996: 8).

Third, the framing process plays a vital role in shaping the mobilization. A combination of political opportunity and a mobilization structure is formed so that the potential for more significant mass action can occur. However, an important element that deserves attention is structural potential. It must be analyzed to ensure that the mediation and social advocacy processes can be fulfilled following the initial 
objectives' mass action. For this reason, an essential component in framing issues in a social movement is defining the problem and its source. Therefore, the achievement prediction of mass action is by the objectives. This activity is a strategic element to fight for the issues raised.

There are three components of framing that can be used as material for determining social movement strategy choices-first, the problem of injustice. The injustice arises from moral indignation caused by policies that are not pro-society, thus creating disappointment. Second, individual identities that are not considered by state policies. This condition shows personal motivation to collectively take action (Tarrow, 1996: 9). Third, the agency refers to the belief that a person can change their living conditions. This context can lead to individual activities to participate in social movements, hoping that they can change the fate of their lives as a result of impartial policies. This kind of conviction becomes a condition in mass action to bring up new agents by providing positive mass movement motivation.

In explaining the theories above, the author concludes that social movements do not evolve from an empty space. Rather, there are many factors that were driving the birth of the mass movement. One of the factors influencing this movement is injustice, welfare, and policies that ignore the public's interests. Therefore, idealized social change, according to this perspective, can change living conditions for the better.

\section{An Orientation shifting of Islamic Student Movement}

Youth have an important role in national development. This role is relevant amid nation's problems that never provide a sense of justice. Social justice issues are the ivory tower in this country until now. In fact, this country has been independent for more than 70 years. It is where the youth must take part in solving complex social problems. The empty-space in the midst of whacking troubles is a hope to be filled up by the youth. Its void can be filled with productive activities. Moreover, youth can give critical contributions to criticize the state, which neglects society's problems. Public policies, which take a side, demands youth, notion, and idea to control the government. In this aspect, youth can contribute to the nation to control public policies that tend to side with market interest.

"Youth or students must play a role in the problems plaguing the nation. Students, as part of the youth, must return to their track as a democratic control force. If there is no control, the government and public administrators tend to prioritize the interests of investors. Moreover, this nation is being confronted directly with globalization without boundaries and has adopted a neoliberal economic system. This system can no longer be denied, along with the development of digital technology. Technology tends to break through the policies that give benefit to digital business growth. For this reason, students are required to control government policies which do not support the public interests (Rozaki, 20I7)." 
The state is a symbol of a president's power. However, a president who does not stand for the public interests must be addressed with social control. Although cabinet members are alumni of Islamic student organizations - IMM, PMII, HMI, and KAMMI - become public officials. Nevertheless, if the system does not take sides with each student organization's ideology, the incumbent political actors are very susceptible to neoliberal economic pragmatism. In this aspect, the ideals of change carried by each of the alumni of the Islamic student movement activists seem trapped in political pragmatism.

"It does not matter if students have affiliation with the government or their senior or alumni who are already become, public officials. Still, students have to pay attention to the organization's roots as a basis for taking actions with critical reasoning. Students should not be trapped in their seniors' political pragmatism so that criticism is blunt (Andi, 20I7a).

Islamic student organizations have experienced a shift in movement orientation. This shift cannot be ignored along with the dullness of the student movement. The analysis of the movement changes is because the student's thinking paradigm tends to pragmatism. Students as intellectuals who have a sense of belonging to social change seemed withered. It happens because students become new entities in society who are less sensitive to the phenomena of injustice and inequality. It is not wrong when students become a new social class in society's structure (Izudin, 2017: 7076; Jurdi, 2013).

On the other hand, the functions of students as agents of control to government's policy are often not lasted forever. There are also some critiques that many student activists are also trapped in a false struggle. This model of struggle was allegedly held by political pragmatism. In this sense, student movement is believed merely as a proxy of political party. Practice politics has become a gap between student idealism. The gulf has hit all elements, both students who enter the professional or politics. It happened because the ideology of student activist organizations was only used when they were still in process.

After finishing organizational activities, students can be trapped in political pragmatism. This condition must be changed both in method and in the mindset of thinking. One of the most genuine offers is to create a cadre of student organizations to become researchers. When facing social problems, being a researcher can be conveyed to the government based on data and facts from the field. The government can hear data-based policy offerings directly.

Rational criticism based on scientific facts is needed. Besides, it can map problems and notes for policy changes, especially when students can implement transformative social advocacy based on the scientific data produced. Therefore, the 
student movement orientation must change. This change requires students to be able to increase individual capacity according to scientific knowledge and facts.

Such conditions can be done if students have the awareness to deepen science and technology. With adaptive abilities, according to science and technology development, it is not impossible when social transformation can be realized. Mastering in science and technology can become the basis for students, especially changes in organizational ideology. As expected, student organizations and activists are no longer solely taboo people. However, it must be a problem solver in a society that experiences structural oppression of hegemony power. Moreover, the free-market era can create spaces and new social classes.

\section{The Dynamics of the Post-Reformation Islamic Student Movement}

The power hegemony popularized by Antonio Gramsci (I89I-I937) influences social movements in the 2Ist century. Gramsci's idea is very contextual with this study, which questions the domination of power because it is driven by physical strength. Gramsci's perspective applies power as an element of the hegemony work tool (Gramsci, 2013; Sugiono, 2008).

This working tool includes the government elements of a country. These instruments tend to take repressive actions and have the nuance of law enforcement. State institutions through legal institutions, military, and police are sometimes like 'simalakama fruit.' State institutions tend to be repressive towards critical groups. It is many victims from the community who end up living in prison. Meanwhile, the state's ethos in covering management deficiencies tends to rule through religious life, education, art, and family (Mustain, 2007).

The power of civil society can prevent the state's repressive actions towards critical communities. This group can establish non-government organizations (NGOs), social and religious organizations, associations, and interest groups (Fakih, I998; nul Hakim, 20II). The grassroots organization is the key for society to avoid the zone of power hegemony.

In this way, the social locus created by critical society becomes the capital to ward off hegemony. This condition does not appear to be significantly different from non-populist policies. However, as a subsystem within the state, hegemony becomes the inspiration for bureaucrats to perpetuate their power. Of course, the power built through this model is an effective way for the authorities to communicate. Positive images are created to promote development trends. With this trend, the state has become real in the eyes of ordinary people. Indeed, if it is urgently critical, the nation's condition is full of crowded problems. Actions of collusion, corruption, and nepotism 
are unfinished problems. Political oligarchy is a crucial phenomenon in a democratic country. Neoliberalism has become the ideology of bureaucrats. Tie rats still roam on both executive and legislative branches. The community seems helpless and blinded by this truly complex problem (Winters, 2013).

The complexity of the country's problems makes students restless. As an educated group, of course, they also feel concerned about this critical condition. However, the student movement has not yet found momentum or has no real common enemy. Bureaucrats are a kind of anti-thesis to the nation's ideology. On the surface, they look like to be defending the interests of society.

Meanwhile, behind their roles, they make a deal that only benefited for few a part of the elite group. The government's weakness is covered by a positive image that always adorns the sides of the screen. A positive impression also covers constructive criticism from students as decorating their images in the virtual world. That is power hegemony applied by the bureaucrats of this country.

Democracy can be a system that blinds students' critical reasoning. The pattern of the student movement has not been used in response to various national issues. The space of freedom merely implies no real implications. This condition creates new problems. The student's critical expression space becomes invisible. The student movement is at a deadlock because elite interests broke some students' idealism; therefore, the real sign of grassroots is only accidental.

Students have felt this unexpected condition. However, the student movement has not found typical momentum. Several Islamic student organizations in Yogyakarta responded to various issues only to strengthen internal requirements. The student movement has not been able to build consolidation across organizations. Besides, the fact that the lack of student movement is because of the national education system's effect. They do not have enough time to carry out social advocacy. The border is that they must finish the subject of study in a short time. The doctrine to graduate immediately without delay, and less support by campus, also reflects students' critical power regression.

"The student movement stagnation is now influenced by many new organizations. It does not include that the campuses that mentioned campaign for the student organization, like the Student Executive Board, are accused of being unachievable. The campus always creates a negative stigma against extra organizations' existence. In addition, the campus considers students who are only diligent in studying, with good achievement and grades. In fact, there is no guarantee that the type of student-made as the standard by the campus authority understands the problems and realities of society (Andi, 20I7)." 
Campus authorities have viewed students negatively and positively since the reform era. This condition is inseparable from the state policy that enforces the Normalisasi Kehidupan Kampus (Normalization of Campus Life) / Badan Koordinasi Kemahasiswaan (Student Coordinating Board)-NKK / BKK. This policy was born in the era of Mendikbud Daoed Joesoef, who issued Decree No. 0I56 / U / 1978 concerning the Normalization of Campus Life. Its policy makes the campus a sterile area from political activity. This decree is also a valid argument for the Student Senate and Student Council's dissolution in each university.

However, the reformation era brought blessings to extra-campus organizations. Student organizations and movements grow on campuses throughout Indonesia. The reform movement has become the inspiration and spirit of the student movement. The implication is that the campus forms a BEM organization starting from the Faculty to the Student Council. The existence of BEM was strengthened by the presence of extracampus organizations that thrived in the reform era. The most powerful presence student organizations in the reform era were KAMMI, HMI, PMII, and IMM.

The reformation has been over and already 20 years old. The ideals of reformation have been realized. Democracy is a manifestation of reformation values. Whoever, the nation's best child in this country, can become a leader without being born from royalty. People who have leadership capability can be realized. Jokowi is a role model product of reform. A simple figure from a village is capable of becoming a president. That is the true meaning of the reform process. However, the nation's journey is not only finished at the stage of growing leadership. The development of a dignified country to achieve justice and prosperity is an important point that must be achieved.

Post-reformation, student organizations experienced a setback, mainly to look for common issues. The student movement becomes the cage's champion, and the only one of the ultimate goals is the campus achievement for some activists. The movement to normalize and return to campus has become a consensus supported by the government and authorities to limit students' political activities. It means that the government's hegemony and the authorities have met a moment of victory in normalizing student activities. This winning chain was obtained through joint consensus without taking repression and oppression against elements of student activists. According to Hegel, this method is used to apply the university channel, which determines the campus community's cognitive structures directly and indirectly. As a result, the consensus formed a hegemony that was finally considered correct intellectually and adequate morally.

Currently, student movement patterns tend to rely on more instructive internal relations. Relations between organizations still rest on the theoretical level as a critical 
awareness of organizational members. The influence of seniors who have become government officials is superior because they built unidirectional communication patterns in determining the organization's future direction and activities.

"The influence of the seniors who sit in the government (executive and legislative) in responding to government policies that are not pro-people? Some things are instructional, and the effect is not significant because of the distance from alumni. Communication tools and through forums, and communication is often cut off (Sofyan, 2017).

According to IMM activists, the organization's response to national issues still rests on seniors' opinions and thoughts who have served in the government. It is even admitted that organizations' demonstrations are often due to seniors' instructions in power even though the issues addressed in the internal organizational discussion process. It means that IMM's ties to senior ruling still happen. Critical issues and activities such as demonstrations still follow the senior's perspective rather than joint decisions and actions independently.

According to Situmorang, the political opportunity mechanism seeks to explain that social movements occur due to changes in the political structure seen as opportunities (Situmorang, 2007: 3). Tarrow also emphasizes that the mechanism of political opportunity in social movements arises when access to state political institutions is open. Political balance can be formed when political elites experience conflicts of interest. This conflict is used for changes that benefit elite groups' collectivity (Tarrow, 1996: 4).

A similar pattern also occurred in PMII. According to PMII activists, seniors are not allowed to influence discourse and discussion as well as reading issues within the internal organization. Based on the struggle values, the discussion theme and reading topic depart from its organization members' critical awareness. "Responding to ongoing issues does depart from the ideas and ideas of friends who are used to reading," said Zen.

In other words, post-reformation Islamic student organizational activities still depend on senior communications who become public officials. This relationship forms a political alliance in addressing national issues. Directly, this alliance only favors its group interests. There are also student organizations that adhere to fundamental organizational values but cannot be separated from their political affiliations' interests.

The student movement's mobilization structure mingled with the power elite interests in creating common issues based on group interests. The mobilization concept is concentrated on informal networks and external organizations in political groups and organizations (Akbar, 20I6). This kind of pattern arises due to the emotional connection between organization members and former senior members. There are similarities between them, including correspondence in ideology, program, goals, mass base, and leadership. 
An accidental movement etymologically has a meaning related to an accidental attribute, accidental property, characteristic quality, or accidental predicate (Arrington, 20I6: 234). In other words, accidental movements can also be interpreted as actions to move under social conditions. It introduces to social dynamics evolutive by describing a social event. Hence, change does not occur suddenly, but it is gradual. In the context of the student movement, Hijrian said: "the condition of post-I998 students had not yet found the common movement direction, the cross-consolidation of student movements had not to move optimally". It means that the post-reformation student movement does not have any clear vision for change.

Aris, the former student president of UIN Sunan Kalijaga Yogyakarta, also emphasized the phenomenon of the accidental movement. According to him, 'The post-I998 student movement was more motivated by historical euphoria, lack of vision, was spontaneous and giddy'. This statement is in line with the accidental movement in addressing various issues. For example, the fuel price hike issue in 20I0, PMII organizations held a demonstration at the T-junction of the UIN Sunan Kalijaga campus in Yogyakarta, followed by other student organizations such as HMI, KAMMI, IMM, GMNI, PMKRI who considered the detrimental policy to the people. It means that the movement is accidental because it only follows the developing dynamics in the country's socio-political sphere. Student organizations' protests also appeared only immediately. After a policy of fuel prices increased, they considered it a burden in the broader community's lives.

Another example is student organizations in Yogyakarta that often encourage a joint alliance, usually the BEM Jogja Alliance, the Cross-Organ Alliance, and others. This action was taken to criticize state policies that were not following the people's needs. This condition makes students have to coordinate with the forces of other movements such as laborers, farmers, fishers, religions, professional associations, and others. Following an organized movement, the power of social advocacy becomes sharper for social change.

In line with a Gramscian perspective, the student movement concept can be categorized as the power of organized civil society. This concept is analyzed through the state's interests and civil society. Civil society consists of various forms of society engaged in vigorous ideological, intellectual activities and hegemonic construction. Thus, civil society is an aggregation or a variety of interests transformed into a universal view as an ideology (Fakih, 1996: 4I).

Meanwhile, students are educated people. Critical movement is the primary aspect of any change agenda. Critical is a characteristic of the student movement because they have a clear organization and a clearly defined vision and struggle mission. According to Tarrow, social movements depart from a theoretical approach that emphasizes four factors: dissatisfaction, resources, political opportunities, and meaning-construction processes (Tarrow, 1996). 
In this way, when responding to an issue, the student organization forces a critical discussion before finally deciding on a joint conclusion (consensus), which is the movement's goal. Students create a well-organized movement by holding an audience. It is done with social advocacy through associations of various groups in the Yogyakarta DPRD building. Students with the People's Movement Alliance (Aliansi Gerakan Rakyat) in 20I4 conveyed their criticisms and aspirations toward the problems contained in the agrarian policy and the development of Yogyakarta New International Airport.

However, this movement did not allow all Islamic student organizations to unite to address agrarian issues. For example, KAMMI looks more at the educational aspect. It is because the construction of education is considered to determine students' level of thinking (cadres) significantly in observing society's control and social development policies. Therefore, when education can develop student character and critical thinking attitude, it will necessarily emerge and inspire them to change movement.

IMM prefers to create critical dialectical movements. Institutional communication is considered an alternative way of criticizing policies without people's will. It means that the movement for change begins when the forum can result in something that should be criticized. Sharing ideas and perspectives is the way PMII takes to foster a critical dialectical movement. It is because sharing ideas is not only considered to build critical power, but also design and discuss the direction of the organizational struggle.

In general, the Islamic student movement is reflected in two parts-first, demonstrations on the street after critical findings at a policy. Second, holding discussions and other open forums to convey aspirations by the struggle's commitment, especially after the reformation movement. Student organizations' efforts in making change movements always create their respective dynamics under the developments and changing times. The most formidable challenge is that demonstrations by taking to the streets to convey aspirations and criticism have now been considered a disgrace for most of the community because they are considered unproductive. Therefore, there needs to be another agenda that is more elegant in conveying social criticism to the government.

\section{Conclusions}

The meta-analysis of the post-reformation Islamic student movement reaps social dynamics. Student movement actions are laden with the interests of political party elites. Besides, the Islamic student movement has a reference and action in action marked by this organized movement. Each Islamic student organization can be identified with AD / ART in realizing social movements as part of social advocacy. 
On the other hand, the post-reformation Islamic student movement tends to be categorized into three parts: resistance to state hegemony, ideological shifting in the Islamic student movement, and the future of the Islamic student movement. This categorization refers to contextualizing problems in those times, coming with international issues and Indonesian nationality. By looking at the real conditions before, the author recommends that there should be a national meeting between the Islamic student organization to achieve an inclusive perspective and repudiate practical political movement. Therefore, it is suggested that all Islamic student organizations should initiate and continue to dialogue forward non-decisive political developments.

\section{Acknowledgment}

Thanks to Abulaka, who condescend to publish this research result. The author reprocessed all of the published research data before into a draft article, which was original data for a thesis report at the UIN Sunan Kalijaga Postgraduate Program.

\section{Funding}

The author does not receive funding assistance for research from any party. This research is purely from field data results when advocating for state policies through consolidation across extra-campus organizations.

\section{Reference}

Akbar, I. (2016). Demokrasi dan Gerakan Sosial (Bagaimana Gerakan Mahasiswa Terhadap Dinamika Perubahan Sosial). Jurnal Wacana Politik, I(2), I07-II5.

Ananta, D. (2017). Politik Oligarki dan Perampasan Tanah di Indonesia: Kasus Perampasan Tanah di Kabupaten Karawang Tahun 20I4. Jurnal Politik, 2(I), IOII35.

Anderson, B. R. O. (1988). Revoloesi Pemoeda: Pendudukan Jepang dan Perlawanan di Jawa I944-I946. Pustaka Sinar Harapan.

Anwar, Y. (1980). Angkatan 66: Sebuah Catatan Harian Mahasiswa. Penerbit Sinar Harapan.

Arrington, C. L. (2016). Accidental Activists. In Accidental Activists. Cornell University Press.

Bayat, A. (2005). Islamism and Social Movement Theory. Third World Quarterly, 26(6), 89I-908.

Buechler, S. M. (1995). New Social Movement Theories. Sociological Quarterly, 36(3), 44I464 .

Fakih, M. (1996). Analisis Gender E Transformasi Sosial. Pustaka Pelajar.

Fakih, M. (1998). Petani dan Penguasa. Yogyakarta: Pustaka Pelajar.

Gramsci, A. (2013). Prison Notebooks: Catatan-Catatan dari Penjara. Yogyakarta: 
Pustaka Pelajar.

Harsasto, P. (2020). Membedah Diskursus Modal Sosial dan Gerakan Sosial: Kasus Penolakan Pabrik Semen di Desa Maitan, Kabupaten Pati. Politika: Jurnal Ilmu Politik, II(I), I8-30.

Izudin, A. (2017). Gerakan Sosial Petani: Pola, Strategi, dan Tantangan di Tengah Modernitas. Samudra Biru.

Izudin, A., \& Suyanto, S. (2019). Gerakan Sosial Warga Parangkusumo Pada Kasus Penggusuran Lahan Geo Maritim Park. Jurnal Sosiologi Reflektif, I4(I), I09-I35.

Jurdi, S. (2013). Gerakan Sosial Islam: Kemunculan, Eskalasi, Pembentukan Blok Politik dan Tipologi Artikulasi Gerakan. Jurnal Politik Profetik, I(I).

Latoszek, M. (2006). "Solidarity"-A Contribution to Social Movement Theory. Polish Sociological Review, I53(I), 39-53.

Nawawi, H. (1992). Instrumen Metodelogi Penelitian Sosial. Yogyakarta: UGM PRESS.

nul Hakim, L. (20II). Governance and New Mode of Governing: Indonesia as a Metaphor. Jurnal Ilmu Sosial Dan Ilmu Politik, I5(2), III-I23.

Rachmawan, D. (20I6). Pola Eskalasi Konflik Pembangunan Infrastruktur: Studi Kasus Pembangunan Waduk Jatigede Kabupaten Sumedang. Masyarakat: Jurnal Sosiologi, I93-2II.

Raillon, F., Tamara, N., \& Simanjuntak, E. S. (1985). Politik dan Ideologi Mahasiswa Indonesia: Pembentukan dan Konsolidasi Orde Baru 1966-1974. Lembaga Penelitian, Pendidikan dan Penerangan Ekonomi dan Sosial (LP3ES).

Situmorang, A. W. (2007). Gerakan Sosial: Studi Kasus Beberapa Perlawanan. Pustaka Pelajar.

Sugiono. (2008). Memahami Penelitian Kualitatif. Bandung: Alfabeta.

Surjomihardjo, A. (1980). Budi Utomo, Cabang Betawi. Pustaka Jaya.

Tarrow, S. (1996). Social Movements in Contentious Politics: A Review Article. JSTOR.

Usman, S. (1999). Arah Gerakan Mahasiswa: Gerakan Politik Ataukah Gerakan Moral? Jurnal Ilmu Sosial Dan Politik, 3(1999).

Widjojo, M. S. (1999). Penakluk Rezim Orde Baru: Gerakan Mahasiswa'98. Pustaka Sinar Harapan.

Winters, J. A. (2013). Oligarchy and Democracy in Indonesia. Indonesia, (96), II-33.

\section{About Author}

Ahmad Izudin is lecturer in Islamic Community Development, UIN Sunan Kalijaga. The author have researchs area around community development and social development. 